\title{
Analisis Kesehatan Laporan Keuangan pada PT Bank Muamalat Indonesia Tbk dengan Menggunakan Metode Camel Tahun 2015 - 2019
}

Muhammad Iqbal Surya Pratikto, Clarissa Belinda Fabrela, Maziyah Mazza Basya Universitas Islam Negeri Sunan Ampel Surabaya

Email: m.iqbal@uinsby.ac.id, clarissabel1508@gmail.com, maziyah.mazza@uinsby.ac.id

\begin{tabular}{l}
\hline Article Info \\
\hline Article history: \\
Published: June 28, 2021 \\
Page: $75-85$ \\
\hline
\end{tabular}

\section{Keyword:}

Kesehatan Bank, Bank Muamalat Indonesia, CAMEL.

\begin{abstract}
Tujuan dari penelitian ini yaitu untuk mengetahui tingkat kesehatan pada PT Bank Muamalat Indonesia Tbk dengan menggunakan metode CAMEL (Capital, Asset Quality, Management, Earning, dan Liquidity) periode tahun 20152019. Hasil penelitian terhadap kesehatan PT Bank Muamalat Indonesia Tbk tahun 2015-2019 menunjukkan bahwa pada rasio CAR, NPF, dan NI dianggap baik, Sedangkan pada rasio PDN dan FDR dianggap cukup baik. Namun pada rasio ROA, ROE, dan BOPO dianggap kurang baik karena seluruh hasil rasionya termasuk dalam kategori kurang sehat.

Kata Kunci : Kesehatan Bank, Bank Muamalat Indonesia, CAMEL.

The purpose of this study is to determine the level of health at PT Bank Muamalat Indonesia Tbk using the CAMEL method (Capital, Asset Quality, Management, Earning, and Liquidity) for the 2015-2019 period. The results of research on the health of PT Bank Muamalat Indonesia Tbk in 2015-2019 show that the ratio of CAR, NPF, and NI is considered good, while the ratio of PDN and FDR is considered quite good. However, the $R O A, R O E$, and BOPO ratios are considered less good because all the results of the ratios are included in the unhealthy category.
\end{abstract}

Keywords : Bank Muamalat Indonesia, CAMEL.

\section{Pendahuluan}

(Pandy Pramadie, 2019) Istilah perbankan tentu tidak asing lagi di kalangan masyarakat saat ini. Sebagai pihak yang paling berperan dalam perbankan, masyarakat sangat tanggap terhadap berbagai macam bentuk layanan atau jasa dari pihak bank yang bertujuan untuk menarik perhatian dan kepercayaan mereka. Di sisi lain, simpati dan kepercayaan masyarakat terhadap suatu bank juga sangat dipengaruhi oleh keadaan keuangan yang

\section{Editorial Office:}

Prodi Ilmu Ekonomi Fakultas Ekonomi dan Bisnis Islam, UIN Sunan Ampel Surabaya

Jl. Ahmad Yani 117 Surabaya, Jawa Timur 60237, Indonesia.

Email: oje@uinsby.ac.id 
ada pada bank tersebut, termasuk pada kesehatan bank itu sendiri. Hal tersebut nantinya akan menjadi suatu acuan tersendiri dalam penilaian tingkat kesehatan bank.

(Pd \& Bkk, 2009) Hampir berbagai macam kejadian tentang perbankan seperti merger dan likuidasi selalu dikaitkan dengan kesehatan suatu bank. Salah satu faktor yang mempengaruhi buruknya tingkat kesehatan suatu bank yaitu disebabkan oleh pembengkakan jumlah kredit yang bermasalah serta adanya kredit macet. Kedua hal tersebut dapat menimbulkan dampak yang buruk bagi perbankan. Oleh karena itu, bank memerlukan suatu kegiatan analisis dengan tujuan agar dapat mengetahui tingkat kondisi kesehatannya setelah melakukan beberapa kegiatan operasional pada jangka waktu tertentu.

(Kartawidjaja, 2020) Perkembangan bank syariah dimulai sejak berdirinya bank syariah pertama di Indonesia pada tahun 1992, yaitu PT Bank Muamalat Indonesia Tbk (PT BMI) di mana secara hukum telah diatur dalam Undang-Undang no. 7 tahun 1992 tentang perbankan, yang kemudian diperbarui dengan Undang-Undang no. 10 tahun 1998. Melihat perkembangan bank syariah yang cukup signifikan, maka dibuatlah peraturan Undang-Undang yang mengatur lebih spesifik tentang bank syariah, yaitu Undang-Undang no. 21 tahun 2008. Dengan adanya Undang-Undang tersebut, maka bank syariah dapat melakukan kegiatan operasionalnya seperti bank konvensional yang sudah ada.

PT Bank Muamalat Indonesia Tbk merupakan Bank Syariah yang pertama kali berdiri di Indonesia pada tanggal 1 November 1991 yang diprakarsai oleh Majelis Ulama Indonesia (MUI) dan juga Pemerintah Indonesia. Kemudian pada tanggal 1 Mei 1992, PT Bank Muamalat Indonesia baru memulai kegiatan operasionalnya. Hingga saat ini, perkembangan PT Bank Muamalat
Indonesia Tbk tentu mengalami kondisi yang tidak stabil.

(Hafiz.Pdf, n.d.) PT Bank Muamalat Indonesia Tbk sempat terkena dampak dari adanya krisis moneter yang memporakporandakan sebagian perekonomian Indonesia pada tahun 1998, di mana hasil dari rasio NPF telah melebihi $60 \%$. Perusahaan mencatat bahwa PT Bank Muamalat Indonesia Tbk mengalami kerugian sebesar Rp 105 miliar. Selain itu, ekuitasnya juga telah mencapai titik terendah yang bernilai sebesar Rp 39,3 miliar di mana hasil tersebut kurang dari sepertiga modal setor awal. Selain kejadian krisis moneter, Pada tahun 2019 Bank Muamalat juga mengalami kondisi yang kurang baik, yaitu dipertengahan tahun Bank Muamalat mengalami kenaikan NPF yang cukup signifikan sehingga Bank Muamalat menghentikan pembiayaan kepada para nasabah. Bank Muamalat mengalami penurunan laba sampai dengan $95 \%$.

Berdasarkan peristiwa tersebut, maka bank harus menyadari bahwa kestabilan tingkat kesehatan harus benarbenar dijaga sebaik mungkin, karena kesehatan bank merupakan salah satu hal yang sangat penting untuk dijaga agar bank dapat menjalankan kegiatan operasional dengan baik sebagaimana fungsinya. Bank yang sehat akan memiliki pengaruh yang baik terhadap kinerja bank itu sendiri. Sedangkan bank yang tidak sehat akan membahayakan dirinya sendiri maupun para nasabah yang nantinya akan menurunkan kepercayaan masyarakat.

Dalam pengawasannya, Bank Indonesia (BI) telah menentukan beberapa aspek yang dapat digunakan untuk menilai kesehatan suatu perbankan, di mana dalam melakukan penilaian tersebut yaitu dengan cara mengkualifikasi beberapa komponen, yaitu Capital (Modal), Asset Quality (Kualitas Aset), Management (Manajemen), Earning (Rentabilitas), dan Liquidity (Likuiditas), atau biasa disebut dengan istilah CAMEL. Penilaian kesehatan bank 
meliputi lima (5) kriteria, yaitu sangat sehat, sehat, cukup sehat, kurang sehat, dan tidak sehat.

Untuk mengukur tingkat kesehatan bank, maka dapat dilakukan dengan menggunakan metode CAMEL, sebagaimana penelitian yang telah dilakukan oleh (Wahyuni, 2020) dengan judul "Analisis Kesehatan Bank Pada Bank Muamalat Indonesia dan Bank Syariah Mandiri Dengan Metode CAMEL". Hasil penelitian tersebut menyatakan bahwa tingkat kesehatan yang dialami oleh Bank Muamalat Indonesia dari tahun 2005-2013 menunjukkan kategori sehat jika dilihat dari rasio CAR, NPM, ROA, dan BOPO. Namun jika dilihat dari rasio LDR, kesehatan Bank Muamalat Indonesia menunjukkan kategori kurang sehat. Sementara itu, tingkat kesehatan yang dialami oleh Bank Syariah Mandiri dari tahun 2005-2013 menunjukkan kategori sehat jika dilihat dari rasio CAR, BOPO, dan LDR. Namun jika dilihat dari rasio NPM dan ROA, kesehatan Bank Syariah Mandiri menunjukkan kategori kurang sehat.

Penelitian lain juga dilakukan oleh (Akbar \& Pandoyo, 2020) dengan judul "Analisis Tingkat Kesehatan Bank Dengan Menggunakan Metode CAMEL Pada PT Bank Muamalat Indonesia Tbk". Hasil penelitian tersebut menyatakan bahwa tingkat kesehatan bank secara keseluruhan dari tahun 2010-2012 termasuk dalam kategori sehat. Hal tersebut dapat dilihat dari aspek Capital, Asset Quality, Management, Earning, dan Liquidity yang ada pada PT Bank Muamalat Indonesia Tbk.

Berdasarkan uraian di atas, maka penulis mengambil penelitian ini dengan judul "Analisis Kesehatan Laporan Keuangan Pada PT Bank Muamalat Indonesia Tbk Dengan Menggunakan Metode CAMEL Tahun 2015-2019".

\section{Kajian Pustaka}

\section{Bank}

Pengertian bank secara sederhana dapat diartikan sebagai suatu badan usaha yang menghimpun dana dari masyarakat dalam bentuk simpanan. Sedangkan menurut Kamus Besar Bahasa Indonesia (KBBI), bank merupakan suatu lembaga keuangan yang menghimpun dan menyalurkan dana masyarakat, terutama memberikan kredit dan jasa dalam lalu lintas pembayaran serta peredaran uang.

(Undang - Undang RI, 1998) Dalam Undang-Undang no. 7 tahun 1992 pasal 1 tentang Perbankan, yang kemudian diubah dengan Undang-Undang no. 10 tahun 1998 menyebutkan bahwa "Bank adalah badan usaha yang menghimpun dana dari masyarakat dalam bentuk simpanan dan menyalurkannya kepada masyarakat dalam bentuk kredit dan atau dalam bentuk-bentuk lainnya dalam rangka meningkatkan taraf hidup masyarakat banyak".

Berdasarkan beberapa definisi di atas, maka dapat disimpulkan bahwa bank merupakan suatu lembaga intermediasi keuangan yang menghimpun dan menyalurkan dana masyarakat sebagai kegiatan utamanya dengan memberikan berbagai macam layanan jasa bank lainnya yang bertujuan untuk meningkatkan taraf hidup masyarakat.

\section{Bank Syariah}

(Andrianto \& Firmansyah, 2019) Bank syariah merupakan bank yang dalam menjalankan kegiatan operasionalnya berlandaskan pada hukum-hukum Islam, di mana dalam kegiatannya tidak membebankan bunga, namun menerapkan prinsip bagi hasil. Imbalan dari bank syariah tergantung dari akad yang dilakukan oleh pihak nasabah dan pihak bank. Akad yang terdapat dalam perbankan syariah pun juga harus sesuai dengan rukun dan syarat akad sebagaimana telah diatur dalam syariat Islam.

Prinsip utama bank syariah adalah hukum Islam yang bersumber dari Al- 
Qur'an dan Hadits. Adapun landasan hukum tentang larangan riba sebagaimana firman Allah SWT dalam Q.S Al-Baqarah (2) ayat 275, yaitu:

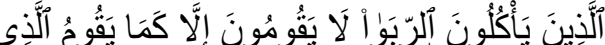

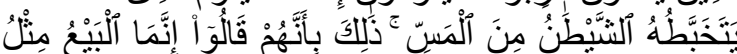

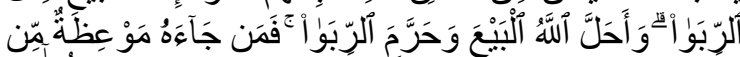

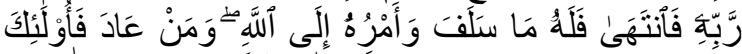

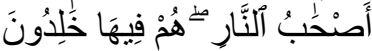

Artinya : "Orang-orang yang memakan (mengambil) riba tidak dapat berdiri melainkan seperti berdirinya orang yang kemasukan syaitan adalah disebabkan mereka berkata (berpendapat), sesungguhnya jual beli itu sama dengan riba, padahal Allah telah menghalalkan jual beli dan mengharamkan riba. Orang-orang yang telah sampai kepadanya larangan dari Tuhannya, lalu terus berhenti (dari mengambil riba), maka baginya apa yang telah diambilnya dahulu (sebelum datang larangan); dan urusannya (terserah) kepada Allah. Orang yang kembali (mengambil riba), maka itu adalah penghuni-penghuni neraka; mereka kekal di dalamnya."

\section{Tingkat Kesehatan Bank}

Kesehatan bank dapat diartikan sebagai kemampuan suatu bank dalam melakukan berbagai macam kegiatan operasional dengan baik, di mana bank mampu melakukan serta memenuhi seluruh kewajibannya sesuai dengan peraturan perbankan yang berlaku.

Bank dapat dikatakan sehat yaitu bank yang mampu untuk menjaga kepercayaan masyarakat serta dapat mendukung efektivitas kebijakan moneter. Selain itu, bank yang sehat merupakan bank yang dapat menjalankan fungsi intermediasi dengan baik.

Tingkat kesehatan bank merupakan suatu hasil penelitian dari berbagai macam aspek yang sangat berpengaruh terhadap kondisi kinerja suatu bank. Dalam menilai tingkat kesehatan suatu bank, maka dapat dilihat dari bagaimana kinerja bank tersebut yang dapat dilakukan dengan cara menganalisis kesehatan laporan keuangan yang ada.

Penilaian tingkat kesehatan bank berfungsi untuk mengevaluasi kinerja bank dalam menerapkan beberapa prinsip, yaitu prinsip kehati-hatian, kepatuhan terhadap ketentuan yang berlaku, serta manajemen risiko. Apabila metode pertumbuhan bisnis tidak sesuai dengan prinsip-prinsip tersebut, maka dapat berpotensi menimbulkan kerugian yang nantinya juga akan mempengaruhi penilaian tingkat kesehatan terhadap bank itu sendiri.

\section{Laporan Keuangan}

Laporan keuangan dapat diartikan sebagai laporan yang menunjukkan kondisi keuangan perusahaan pada saat ini atau dalam suatu periode tertentu (Kasmir, 2019). Dalam praktiknya, laporan keuangan perusahaan harus dibuat dan disusun sesuai dengan aturan yang berlaku. Hal ini dapat memudahkan untuk membaca dan memahami laporan keuangan secara jelas mengenai data yang disajikan, karena laporan keuangan yang disajikan oleh perusahaan tersebut sangat penting bagi manajemen maupun pemilik perusahaan itu sendiri. Oleh karena itu, perusahaan dapat mengetahui posisi perusahaan saat ini setelah melakukan analisis laporan keuangan yang ada.

(Hery, 2015) Pada umumnya, terdapat empat bentuk laporan keuangan yang ada pada suatu perusahaan, yaitu laporan neraca, laba rugi, laporan perubahan modal, serta aliran kas.

Adapun tujuan dari adanya laporan keuangan yaitu untuk memberikan informasi mengenai keuangan perusahaan pada periode tertentu. Selain itu, laporan keuangan juga dapat memudahkan manajemen dalam menilai kinerja suatu perusahaan. Penilaian kinerja tersebut akan menjadi sebuah patokan atau ukuran apakah manajemen mampu untuk menjalankan kebijakan-kebijakan yang telah ditetapkan oleh perusahaan. 


\section{Metode Penelitian}

(Rini Jafar, Salim Basalamah, 2020) Penelitian ini menggunakan metode deskriptif kuantitatif, yaitu dengan memberikan gambaran mengenai tingkat kesehatan perbankan syariah dalam bentuk angka-angka yang kemudian diuraikan dalam bentuk pembahasan.

Untuk menganalisis tingkat kesehatan pada PT Bank Muamalat Indonesia Tbk tahun 2015-2019, maka dapat menggunakan metode CAMEL yang memiliki beberapa indikator, di antaranya yaitu:

\section{Capital (Modal)}

Modal merupakan salah satu faktor yang sangat penting dalam penilaian tingkat kesehatan bank, karena faktor tersebut berhubungan dengan kemampuan pengembangan usaha suatu bank serta untuk menampung risiko kerugian. Di samping itu, modal juga merupakan salah satu hal sangat penting agar dapat menjaga kepercayaan masyarakat terhadap perkembangan dan kemajuan bank itu sendiri.

(Asraf, 2020) Penilaian terhadap faktor permodalan dapat diukur menggunakan indikator rasio kecukupan modal atau Capital Adequacy Ratio (CAR). Rasio CAR dapat diartikan sebagai rasio kecukupan modal yang menunjukkan kemampuan suatu bank dalam mengukur, mengidentifikasi, serta mengontrol berbagai macam risiko yang berpengaruh terhadap besarnya modal. Berikut adalah rumus dalam menghitung CAR:

$$
\mathrm{CAR}=\frac{\text { Modal }}{\text { ATMR }} \times 100 \%
$$

Tabel 1. Klasifikasi Peringkat CAR

\begin{tabular}{|c|c|c|}
\hline Peringkat & Nilai Komposit & Predikat \\
\hline 1 & CAR $\geq 12 \%$ & Sangat Sehat \\
\hline 2 & $\begin{array}{c}9 \% \leq \mathrm{CAR}< \\
12 \%\end{array}$ & Sehat \\
\hline 3 & $\begin{array}{c}8 \% \leq \mathrm{CAR}< \\
9 \%\end{array}$ & Cukup Sehat \\
\hline 4 & $\begin{array}{c}6 \% \leq \mathrm{CAR}< \\
8 \%\end{array}$ & Kurang Sehat \\
\hline 5 & $\mathrm{CAR} \leq 6 \%$ & Tidak Sehat \\
\hline
\end{tabular}

\section{Asset Quality (Kualitas Aset)}

Aset adalah segala sesuatu yang dimiliki oleh individu, perusahaan, maupun pemerintah di mana hal tersebut dapat dinilai secara finansial. Aset juga merupakan suatu hal yang tidak kalah pentingnya jika dibandingkan dengan modal, karena aset berfungsi untuk menopang jalannya suatu usaha perbankan.

Penilaian terhadap faktor kualitas aset dapat diukur menggunakan indikator Non Performing Finance (NPF). Berikut adalah rumus dalam menghitung NPF:

$$
\begin{aligned}
& \text { NPF }=\frac{\text { Kredit Bermasalah }}{\text { Total Kredit }} \times \mathbf{1 0 0 \%} \\
& \text { Tabel 2. Klasifikasi Peringkat NPF }
\end{aligned}
$$

\begin{tabular}{|c|c|c|}
\hline Peringkat & Nilai Komposit & Predikat \\
\hline 1 & $\mathrm{NPF} \leq 2 \%$ & Sangat Sehat \\
\hline 2 & $\begin{array}{c}2 \% \leq \mathrm{NPF}< \\
5 \%\end{array}$ & Sehat \\
\hline 3 & $\begin{array}{c}5 \% \leq \mathrm{NPF}< \\
8 \%\end{array}$ & Cukup Sehat \\
\hline 4 & $\begin{array}{c}8 \% \leq \mathrm{NPF}< \\
12 \%\end{array}$ & Kurang Sehat \\
\hline 5 & $\mathrm{NPF} \geq 12 \%$ & Tidak Sehat \\
\hline
\end{tabular}

\section{Management (Manajemen)}

(Sulisnaningrum, 2019) Manajemen merupakan salah satu tolok ukur masyarakat terhadap suatu perbankan dengan melihat apakah pengelolaan bank tersebut sudah sesuai dengan asas-asas perbankan yang dinilai sehat atau tidak sehat. Manajemen perbankan juga dapat diartikan sebagai suatu ilmu yang lebih berfokus pada hal pengaturan dan pengelolaan seluruh kegiatan operasional suatu perbankan. Pada intinya, manajemen perbankan bertujuan untuk mengatur seluruh kegiatan operasional bank. Hal tersebut dilakukan agar tidak adanya dana yang tertimbun secara berlebihan pada bank yang bersangkutan. 
Selain masalah kegiatan operasional, manajemen perbankan juga memiliki tujuan untuk menganalisa berbagai macam kegiatan penyaluran pembiayaan masyarakat.

Penilaian terhadap faktor manajemen dapat diukur menggunakan indikator Posisi Devisa Netto (PDN). Berikut adalah rumus dalam menghitung NPF:

PDN $=\frac{\text { Selisih Aset } \& \text { Liabilitas Valas }}{\text { Total Modal }} \times 100 \%$

Tabel 3. Klasifikasi Peringkat PDN

\begin{tabular}{|c|c|c|}
\hline Peringkat & Nilai Komposit & Predikat \\
\hline 1 & $\begin{array}{c}\text { Tidak ada } \\
\text { pelanggaran rasio } \\
\text { PDN }\end{array}$ & Sangat Sehat \\
\hline 2 & $\begin{array}{c}\text { Tidak ada } \\
\text { pelanggaran rasio } \\
\text { PDN namun pernah } \\
\text { melakukan } \\
\text { pelanggaran dan } \\
\text { telah diselesaikan }\end{array}$ & Sehat \\
\hline 3 & $\begin{array}{c}\text { Pelanggaran rasio } \\
\text { PDN }>0 \% \text { sampai } \\
\text { dengan }<10 \%\end{array}$ & Cukup Sehat \\
\hline 4 & $\begin{array}{c}\text { Pelanggaran rasio } \\
\text { PDN > 10\% } \\
\text { sampai dengan } \\
25 \%\end{array}$ & Kurang Sehat \\
\hline 5 & $\begin{array}{c}\text { Pelanggaran rasio } \\
\text { PDN > 25\% }\end{array}$ & Tidak Sehat \\
\hline
\end{tabular}

\section{Earning (Rentabilitas)}

(Basuki, 2019) Rasio rentabilitas merupakan suatu perbandingan antara laba setelah pajak dengan modal atau laba sebelum pajak dengan total aset yang dimiliki oleh bank pada periode tertentu. Rentabilitas juga dapat diartikan sebagai suatu alat yang digunakan untuk mengukur efisiensi serta profitabilitas terhadap usaha yang telah dicapai oleh suatu bank.

(Surya Pratikto et al., 2020) Penilaian terhadap faktor rentabilitas dapat diukur menggunakan beberapa indikator, yaitu
ROA (Return On Assets), ROE (Return On Equity), BOPO (Biaya Operasional Terhadap Pendapatan Operasional), dan NI (Net Imbalan). Berikut adalah rumus dalam menghitung ROA, ROE, BOPO, dan NI:

a. Rumus ROA (Return On Assets)

$$
\text { ROA }=\frac{\text { Laba Sebelum Pajak }}{\text { Rata }- \text { rata Total Aset }} \times 100 \%
$$

Tabel 4. Klasifikasi Peringkat ROA

\begin{tabular}{|c|c|c|}
\hline Peringkat & Nilai Komposit & Predikat \\
\hline 1 & $\mathrm{ROA} \geq 2 \%$ & Sangat Sehat \\
\hline 2 & $\begin{array}{c}1,26 \% \leq \mathrm{ROA}< \\
5 \%\end{array}$ & Sehat \\
\hline 3 & $\begin{array}{c}0,51 \% \leq \mathrm{ROA}< \\
1,25 \%\end{array}$ & Cukup Sehat \\
\hline 4 & $\begin{array}{c}0 \% \leq \mathrm{ROA}< \\
0,5 \%\end{array}$ & Kurang Sehat \\
\hline 5 & $\mathrm{ROA}<0 \%$ & Tidak Sehat \\
\hline
\end{tabular}

b. Rumus ROE (Return On Equity)

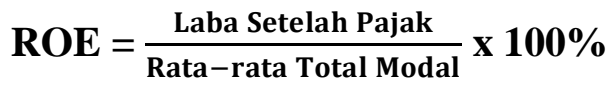

Tabel 5. Klasifikasi Peringkat ROE

\begin{tabular}{|c|c|c|}
\hline Peringkat & Nilai Komposit & Predikat \\
\hline 1 & ROE $\geq 20 \%$ & Sangat Sehat \\
\hline 2 & $\begin{array}{c}12,51 \% \leq \mathrm{ROE} \\
<20 \%\end{array}$ & Sehat \\
\hline 3 & $\begin{array}{c}5,01 \% \leq \mathrm{ROE}< \\
12,5 \%\end{array}$ & Cukup Sehat \\
\hline 4 & $0 \% \leq \mathrm{ROE}<5 \%$ & Kurang Sehat \\
\hline 5 & $\mathrm{ROE}<0 \%$ & Tidak Sehat \\
\hline
\end{tabular}

c. Rumus BOPO

$$
\text { BOPO }=\frac{\text { Biaya Operasional }}{\text { Pendapatan Operasional }} \times 100 \%
$$


Tabel 6. Klasifikasi Peringkat BOPO

\begin{tabular}{|c|c|c|}
\hline Peringkat & Nilai Komposit & Predikat \\
\hline 1 & Kurang dari 88\% & $\begin{array}{c}\text { Sangat } \\
\text { Sehat }\end{array}$ \\
\hline 2 & $\begin{array}{c}89 \% \text { sampai dengan } \\
93 \%\end{array}$ & Sehat \\
\hline 3 & $\begin{array}{c}94 \% \text { sampai dengan } \\
96 \%\end{array}$ & $\begin{array}{c}\text { Cukup } \\
\text { Sehat }\end{array}$ \\
\hline 4 & $\begin{array}{c}97 \% \text { sampai dengan } \\
100 \%\end{array}$ & $\begin{array}{c}\text { Kurang } \\
\text { Sehat }\end{array}$ \\
\hline 5 & Lebih dari 100\% & $\begin{array}{c}\text { Tidak } \\
\text { Sehat }\end{array}$ \\
\hline
\end{tabular}

d. Rumus NI (Net Imbalan)

$\mathrm{NI}=\frac{\text { Pendapatan Imbal }}{\text { Rata-rata Aset Produktif }} \times \mathbf{1 0 0 \%}$

Tabel 7. Klasifikasi Peringkat NI

\begin{tabular}{|c|c|c|}
\hline Peringkat & Nilai Komposit & Predikat \\
\hline 1 & $\mathrm{NI} \geq 6,5 \%$ & $\begin{array}{c}\text { Sangat } \\
\text { Sehat }\end{array}$ \\
\hline 2 & $2,01 \% \leq \mathrm{NI}<6,5 \%$ & Sehat \\
\hline 3 & $1,5 \% \leq \mathrm{NI}<2 \%$ & $\begin{array}{c}\text { Cukup } \\
\text { Sehat }\end{array}$ \\
\hline 4 & $0 \% \leq \mathrm{NI}<1,49 \%$ & $\begin{array}{c}\text { Kurang } \\
\text { Sehat }\end{array}$ \\
\hline 5 & $\mathrm{NI}<0 \%$ & $\begin{array}{c}\text { Tidak } \\
\text { Sehat }\end{array}$ \\
\hline
\end{tabular}

\section{Liquidity (Likuiditas)}

(Putri \& Marlius, 2018) Likuiditas merupakan kemampuan suatu perusahaan dalam memenuhi kewajiban finansial jangka pendek yang ditunjukkan oleh besar kecilnya aktiva lancar. Penilaian likuiditas ini bertujuan untuk mengevaluasi kemampuan suatu bank dalam kecukupan manajemen risiko likuiditas serta memelihara tingkat likuiditas yang memadai.

Penilaian terhadap faktor likuiditas dapat diukur menggunakan indikator Finance to Deposit Ratio (FDR). Berikut adalah rumus dalam menghitung FDR:

FDR $=\frac{\text { Jumlah Kredit yang diberikan }}{\text { Total Dana Pihak Ketiga }} \times 100 \%$

Tabel 8. Klasifikasi Peringkat FDR

\begin{tabular}{|c|c|c|}
\hline Peringkat & Nilai Komposit & Predikat \\
\hline 1 & $\begin{array}{c}\text { Rasio }>50 \% \\
\text { sampai dengan } \leq \\
75 \%\end{array}$ & $\begin{array}{c}\text { Sangat } \\
\text { Sehat }\end{array}$ \\
\hline 2 & $\begin{array}{c}\text { Rasio }>75 \% \\
\text { sampai dengan } \leq \\
85 \%\end{array}$ & Sehat \\
\hline 3 & $\begin{array}{c}\text { Rasio }>85 \% \\
\text { sampai dengan } \leq \\
100 \%\end{array}$ & $\begin{array}{c}\text { Cukup } \\
\text { Sehat }\end{array}$ \\
\hline 4 & $\begin{array}{c}\text { Rasio }>100 \% \\
\text { sampai dengan } \leq \\
120 \%\end{array}$ & $\begin{array}{c}\text { Kurang } \\
\text { Sehat }\end{array}$ \\
\hline 5 & $>120 \%$ & Tidak Sehat \\
\hline
\end{tabular}

\section{Hasil dan Pembahasan}

\section{Capital (Modal)}

Gambar 1. Grafik hasil penilaian rasio CAR PT Bank Muamalat Indonesia Tbk Tahun 2015-2019

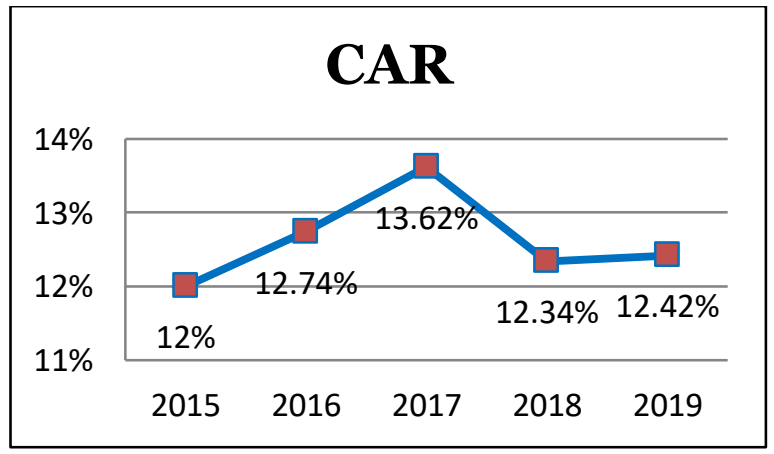

Sumber: Data diolah

Berdasarkan grafik pada gambar 1 di atas, dapat diketahui bahwa rasio CAR pada tahun 2015 yaitu sebesar $12,00 \%$, kemudian pada tahun 2016 mengalami kenaikan menjadi sebesar $12,74 \%$, dan pada tahun 
2017 juga mengalami kenaikan menjadi sebesar 13,62\%. Namun pada tahun 2018 mengalami penurunan menjadi sebesar 12,34\%, dan pada tahun 2019 kembali mengalami kenaikan menjadi sebesar 12,42\%. Jika dilihat dari tabel klasifikasi peringkat $\mathrm{CAR}$, maka dapat disimpulkan bahwa CAR pada PT Bank Muamalat Indonesia Tbk pada tahun 2015 sampai dengan tahun 2019 termasuk dalam kategori sangat sehat.

\section{Asset Quality (Kualitas Aset)}

Gambar 2. Grafik hasil penilaian rasio NPF PT Bank Muamalat Indonesia Tbk Tahun 2015-2019

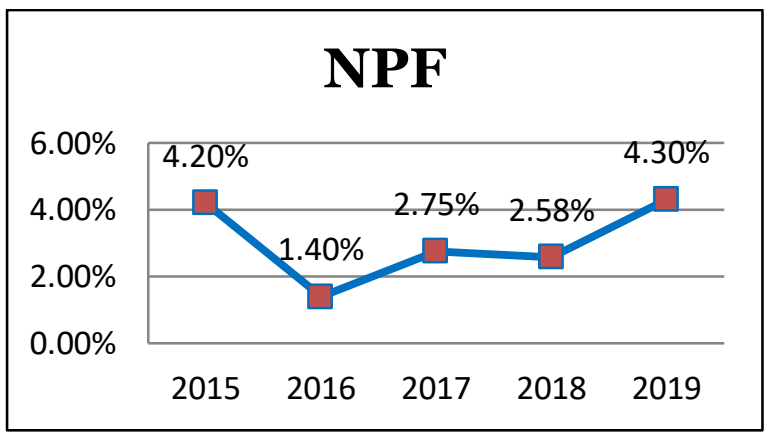

Sumber: Data diolah

Berdasarkan grafik pada gambar 2 di atas, dapat diketahui bahwa rasio NPF pada tahun 2015 yaitu sebesar 4,20\% dan termasuk dalam kategori sehat, sedangkan pada tahun 2016 mengalami penurunan menjadi sebesar $1,40 \%$ yang artinya semakin baik karena termasuk dalam kategori sangat sehat. Kemudian pada tahun 2017 mengalami kenaikan menjadi sebesar $2,75 \%$ dan termasuk dalam kategori sehat. Sementara itu, pada tahun 2018 mengalami penurunan menjadi sebesar $2,58 \%$, dan pada tahun 2019 kembali mengalami kenaikan menjadi sebesar 4,30\%. Meskipun pada saat 2019 mengalami kenaikan yang cukup signifikan dan pembiayaan sempat dihentikan sementara, namun pada akhir tahun 2019 Bank Muamalat mampu menekan jumlah kenaikan NPF sehingga tidak sampai pada kategori Cukup Sehat.

\section{Management (Manajemen)}

Gambar 3. Grafik hasil penilaian rasio NPF PT Bank Muamalat Indonesia Tbk Tahun 2015-2019

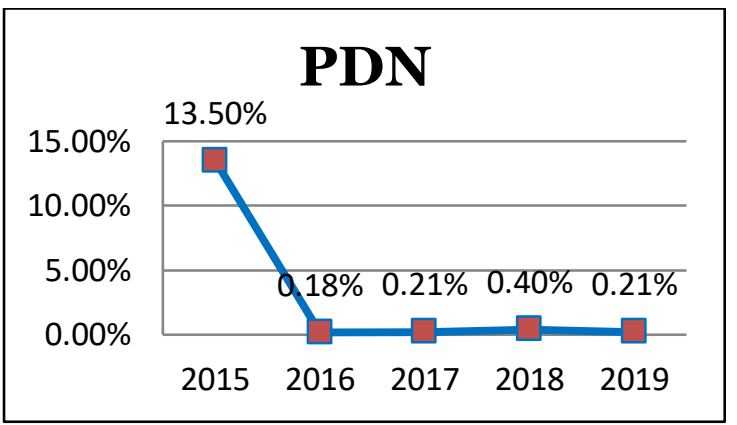

Sumber: Data diolah

Berdasarkan grafik pada gambar 3 di atas, dapat diketahui bahwa rasio PDN pada tahun 2015 yaitu sebesar 13,50\% dan termasuk dalam kategori kurang sehat. Sedangkan pada tahun 2016 mengalami penurunan menjadi sebesar $0,18 \%$ dan termasuk dalam kategori cukup sehat. Kemudian pada tahun 2017 mengalami kenaikan menjadi sebesar $0,21 \%$, dan pada tahun 2018 juga mengalami kenaikan menjadi sebesar $0,40 \%$ namun masih termasuk dalam kategori cukup sehat. Sementara itu, pada tahun 2019 kembali mengalami penurunan menjadi sebesar $0,21 \%$ di mana hal tersebut masih termasuk dalam kategori cukup sehat.

\section{Earning (Rentabilitas)}

\section{a. ROA (Return On Assets)}

Gambar 4. Grafik hasil penilaian rasio ROA PT Bank Muamalat Indonesia Tbk Tahun 2015-2019

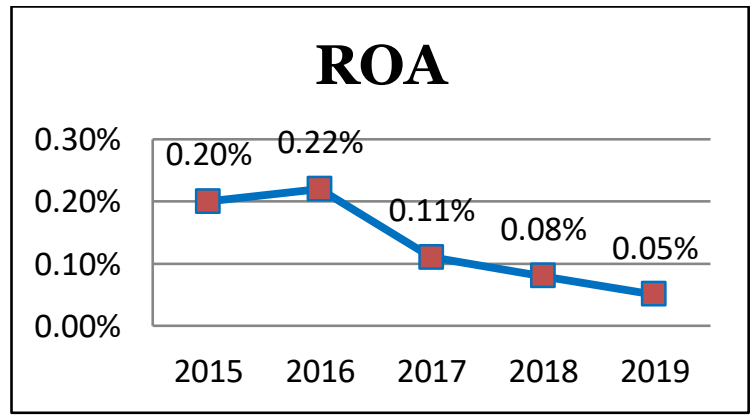

Sumber: Data diolah 
Berdasarkan grafik pada gambar 4 di atas, dapat diketahui bahwa rasio ROA pada tahun 2015 yaitu sebesar $0,20 \%$, dan pada tahun 2016 mengalami kenaikan menjadi sebesar $0,22 \%$. Untuk ROA pada tahun 2017-2019 terus mengalami penurunan. Hal tersebut dapat dilihat dari ROA pada tahun 2017 yaitu sebesar $0,11 \%$, kemudian pada tahun 2018 menjadi sebesar $0,08 \%$, dan pada tahun 2019 menjadi sebesar $0,05 \%$. Jika dilihat dari tabel klasifikasi peringkat ROA, maka dapat disimpulkan bahwa ROA pada PT Bank Muamalat Indonesia Tbk tahun 2015-2019 termasuk dalam kategori kurang sehat.

\section{b. ROE (Return On Equity)}

Gambar 5. Grafik hasil penilaian rasio ROE PT Bank Muamalat Indonesia Tbk Tahun 2015-2019

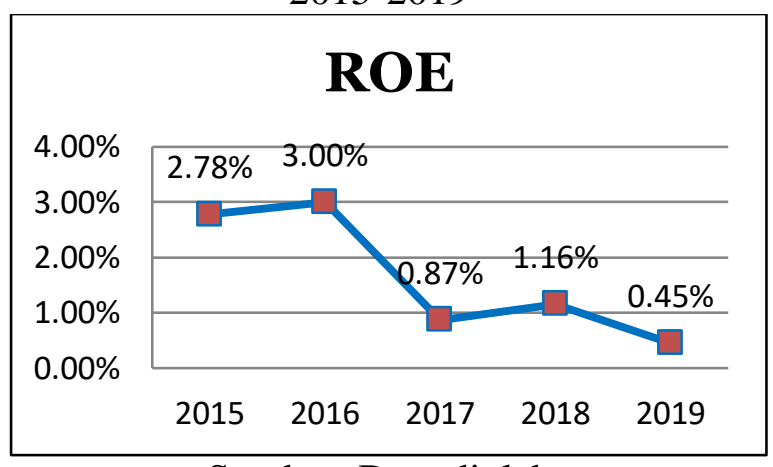

Sumber: Data diolah

Berdasarkan grafik pada gambar 5 di atas, dapat diketahui bahwa rasio ROE pada tahun 2015-2019 dapat dikatakan mengalami fluktuatif. Terlihat pada tahun 2015 yaitu sebesar $2,78 \%$, dan pada tahun 2016 mengalami kenaikan menjadi sebesar 3,00\%. Namun pada tahun 2017 mengalami penurunan menjadi sebesar 0,87\%. Sementara itu, pada tahun 2018 kembali mengalami kenaikan menjadi sebesar 1,16\%, dan pada tahun 2019 kembali mengalami penurunan menjadi sebesar 0,45\%. Jika dilihat dari tabel klasifikasi peringkat ROE, maka dapat disimpulkan bahwa ROE pada PT Bank Muamalat Indonesia Tbk tahun 2015-2019 termasuk dalam kategori kurang sehat.

\section{c. BOPO}

Gambar 6. Grafik hasil penilaian rasio BOPO PT Bank Muamalat Indonesia Tbk Tahun 2015-2019

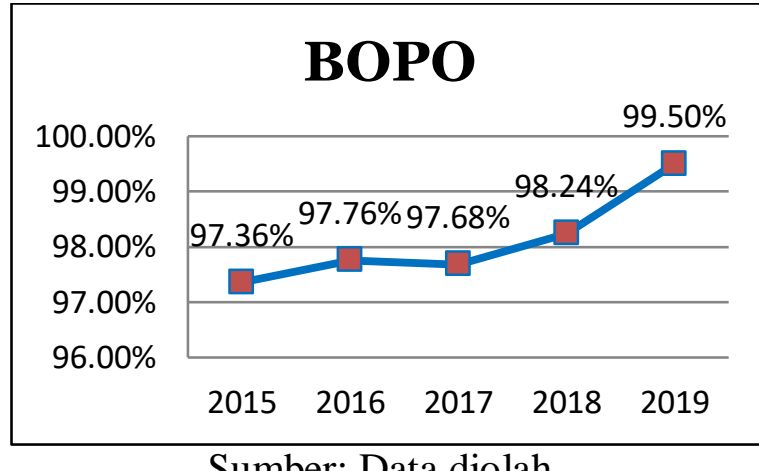

Berdasarkan grafik pada gambar 6 di atas, dapat diketahui bahwa rasio BOPO pada tahun 2015 yaitu sebesar $97,36 \%$, dan pada tahun 2016 mengalami kenaikan menjadi sebesar 97,76\%. Kemudian pada tahun 2017 mengalami penurunan menjadi sebesar $97,68 \%$. Sementara itu, pada tahun 2018 kembali mengalami kenaikan menjadi sebesar 98,24\%, dan pada tahun 2019 juga mengalami kenaikan menjadi sebesar 99,50\%. Jika dilihat dari tabel klasifikasi peringkat BOPO, maka dapat disimpulkan bahwa BOPO pada PT Bank Muamalat Indonesia Tbk tahun 2015-2019 termasuk dalam kategori kurang sehat. Kenaikan BOPO yang cukup signifikan terjadi pada tahun 2019, ini terjadi dikarenakan Bank Muamalat melakukan kegiatan besar besaran dalam hal menagih nasabah nasabah yang masuk dalam kategori NPF. Kegiatan tersebut membuat kenaikan BOPO melonjak cukup signifikan pada tahun 2019 dan masuk dalam kategori kurang sehat. Hal tersebut harus segera ditangani pada tahun tahun selanjutnya.

\section{d. NI (Net Imbalan)}

Gambar 7. Grafik hasil penilaian rasio NI PT Bank Muamalat Indonesia Tbk Tahun 2015-2019 


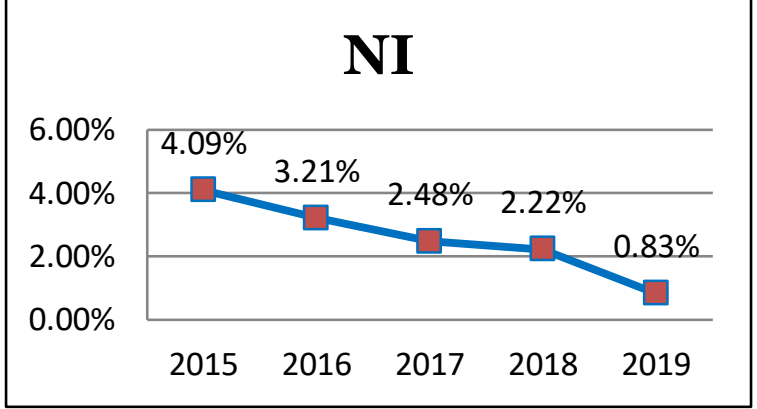

Sumber: Data diolah

Berdasarkan grafik pada gambar 7 di atas, dapat diketahui bahwa rasio NI pada tahun 2015-2019 terus mengalami penurunan. Hal tersebut dapat dilihat dari NI pada tahun 2015 yaitu sebesar $4,09 \%$, dan pada tahun 2016 turun menjadi sebesar 3,21\%. Kemudian pada tahun 2017 mengalami penurunan menjadi sebesar 2,48\%, dan pada tahun 2018 turun menjadi sebesar 2,22\%. Dapat diketahui bahwa rasio NI pada tahun 2015-2018 tersebut termasuk dalam kategori sehat. Sementara itu, pada tahun 2019 juga mengalami penurunan menjadi sebesar $0,83 \%$ namun termasuk dalam kategori kurang sehat.

\section{Liquidity (Likuiditas)}

Gambar 8. Grafik hasil penilaian rasio FDR PT Bank Muamalat Indonesia Tbk Tahun 2015-2019

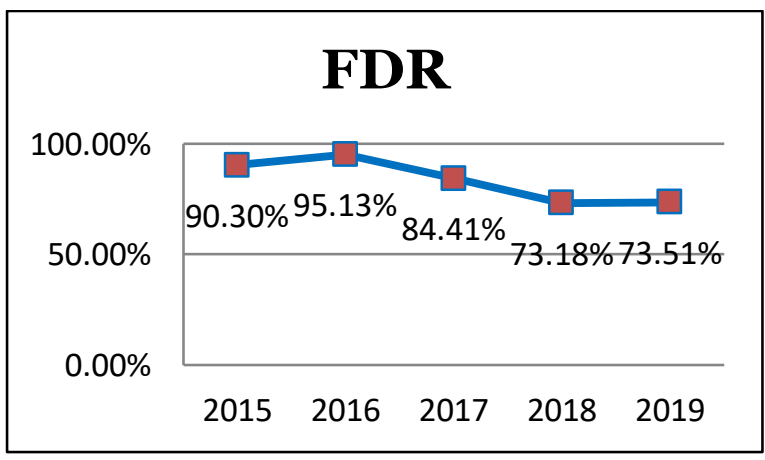

Sumber: Data diolah

Berdasarkan grafik pada gambar 8 di atas, dapat diketahui bahwa rasio FDR pada tahun 2015 yaitu sebesar 90,30\%, kemudian pada tahun 2016 mengalami kenaikan menjadi sebesar $95,13 \%$ di mana hal tersebut termasuk dalam kategori cukup sehat. Sedangkan pada tahun 2017 mengalami penurunan menjadi sebesar $84,41 \%$ namun termasuk dalam kategori sehat. Sementara itu, pada tahun 2018 juga mengalami penurunan menjadi sebesar $73,18 \%$, dan pada tahun 2019 mengalami kenaikan menjadi sebesar 73,51\%. Dapat diketahui bahwa rasio FDR pada tahun 2018-2019 tersebut termasuk dalam kategori sangat sehat.

\section{Kesimpulan}

Berdasarkan hasil analisis di atas, maka dapat disimpulkan bahwa pada tahun 2015-2019, rasio CAR termasuk dalam kategori sangat sehat. Kemudian rasio NPF pada tahun 2015-2019 termasuk dalam kategori sehat, namun pada tahun 2016 termasuk dalam kategori sangat sehat. Sementara itu, untuk rasio PDN pada tahun 2015-2019 termasuk dalam kategori cukup sehat, namun pada tahun 2015 termasuk dalam kategori kurang sehat.

Untuk rasio ROA, ROE, dan BOPO pada tahun 2015-2019 berada dalam kondisi kurang sehat. Kemudian pada tahun 20152019, rasio NI termasuk dalam kategori sehat, namun pada tahun 2019 termasuk dalam kategori kurang sehat. Sementara itu, rasio FDR pada tahun 2015-2016 termasuk dalam kategori cukup sehat. Pada tahun 2017, rasio FDR termasuk dalam kategori sehat, dan pada tahun 2018-2019, rasio FDR termasuk dalam kategori sangat sehat.

\section{SARAN}

Berdasarkan kesimpulan di atas, maka saran yang dapat diambil yaitu diharapkan kepada PT Bank Muamalat Indonesia Tbk agar dapat meningkatkan kembali tingkat kesehatannya dengan menyusun berbagai kebijakan, terutama yang berdasarkan lima faktor seperti Capital, Asset Quality, Management, Earning, dan Liquidity agar mampu bersaing dengan perusahaan sejenis dalam menghadapi persaingan global. Bank Muamalat juga harus membuat strategi agar NPF tidak meningkat ditahun - tahun 
selanjutnya dan ROA, ROE, BOPO, dan NI bisa masuk dalam kategori sehat.

\section{Daftar Pustaka}

Andrianto, \& Firmansyah, M. A. (2019). Manajemen Bank Syariah ( Implementasi Teori dan Praktek ). CV.Penerbit Qiara Media, 30.

Asraf, A. (2020). Analisa Kinerja Keuangan Bank Muamalat Indonesia Dibandingkan Dengan Bank Bri. Jurnal Apresiasi Ekonomi, 8(1), 108116.

https://doi.org/10.31846/jae.v8i1.278

Hery. (2015). ISSN 2303-1174 R. Saleo., S. Murni., T.O.Rotinsulu. Analisis Tingka Kesehatan Bank .Teori Akuntansi, 5(2), 2143-2149.

Pandy Pramadie, L. R. J. dan ibu R. M. (2019). Analisis Penilaian Tingkat Kesehatan Pada Pt.Bank Muamalat Indonesia, Tbk Periode 2010 - 2012 Dengan Menggunakan Metode Camel. Journal of Chemical Information and Modeling, 53(9), 1689-1699.

Pd, P., \& Bkk, B. P. R. (2009). Berdasarkan Metode Camel.

Putri, Y. A., \& Marlius, D. (2018). Analisis Tingkat Kesehatan Bank Pada Pt. Bank Perkreditan Rakyat (Bpr) Jorong Kampuang Tangah Pariaman Cabang Padang.1-10. https://doi.org/10.31227/osf.io/r98pv

Rini Jafar, Salim Basalamah, S. R. (2020). Analisis Kesehatan Keuangan Perbankan Syariah Di Indonesia Menggunakan Metode CAMEL. 3(1), $1-9$.

Sulisnaningrum, E. (2019). Analisis Kinerja Keuangan Bank Dengan Metode Camel Pada Bank Muamalat Dan Bank Syariah Mandiri Di Surabaya. Akuntansi Jaya Negara, 11(1), 1-9.
Surya Pratikto, M. I., Safitri, G. A., \& Basya, M. M. (2020). Analisis Tingkat Kesehatan Bank melalui Pendekatan RGEC (Risk Profile, Good Corporate Governance, Earning, Capital) Tahun 2014-2018 (Studi Pada PT Bank Bri Syariah (Persero) Tbk.). El-Qist : Journal of Islamic Economics and Business (JIEB), 9(2), 128-142. https://doi.org/10.15642/elqist.2019.9. 2.128-142

Undang - Undang RI, B. I. (1998). UndangUndang Republik Indonesia Nomor 7 Tahun 1992 Tentang Perbankan. Bank Indonesia, 1-65. 